\title{
DEVELOPING THE COMPETENCE OF REPRESENTING THE TOPOGRAPHY BY DISCRETE COLOUR BANDS METHOD
}

\author{
GABRIELA OSACI-COSTACHE \\ University of Bucharest, Faculty of Geography, Bucharest, Romania, \\ e-mail: gabrielaosaci68@yahoo.com; gabriela.osacicostache@geo.unibuc.ro
}

\section{OCTAVIAN COCOŞ}

University of Bucharest, Faculty of Geography, Bucharest, Romania, e-mail: octaviancocos@yahoo.com

(Received: January 2018; in revised form: February 2018)

\begin{abstract}
The present study describes a teaching experiment aimed at the integrated development of competences at various study subjects. According to the curriculum, the students in Cartography at the Faculty of Geography (University of Bucharest) should learn how to make a hypsometric map by using the computer as early as the first semester of the $1^{\text {st }}$ year of study. However, when using the software, they are not able to understand the interpolation algorithm lying "behind" the command. Besides, the teaching experience of the authors shows that most students use the various commands of the GIS software or computer-assisted cartography programs only because they exist, without considering the use of a particular command or algorithm. Although the hypsometric map is widely used, many cartographic representations of this kind contain errors that are derived from the superficial understanding of the basic concepts. Consequently, we made an experiment aimed at correlating a number of notions, concepts and procedures. Using the same basemap (a spot elevation map), the students were able to develop the competence of interpolating and manually drawing contour maps (during the Land Surveying class). Subsequently, once they understood these principles, they developed the competence of making a digital hypsometric map by using the tinting method, starting from spot elevations and not from contour lines (at Methods and Techniques of Cartographic Representation). The advantage was that the students were able to understand the fundamentals of a particular program algorithm, to apply the various procedures based on understanding them and to correlate their knowledge. All these are premises for creativity, for a correct use of procedures (irrespective of the involved topography) and for raising the quality of the geographic higher education.
\end{abstract}

Keywords: spot elevations, contour lines interpolation, contour lines, hypsometric steps, hypsometric map 


\section{INTRODUCTION}

The authors of the present study have found that in the first year of college, students encounter difficulties in understanding the principle of representing the topography by using the contour lines method, in interpreting the terrain on maps, and in making the right cartographic choices (OsaciCostache et al., 2013). Consequently, drawing thematic maps of terrain becomes a difficult task if we want the student to think and understand the representation and not simply to turn into a technician who just presses a button. Besides, the programs offer various possibilities, not all of them adequate for the input data, and the geographer or cartographer must know what to choose. In the context in which the use of software (GIS, computerassisted cartography) is indispensable for Geography, the risk of preparing only "technicians" and not genuine geographers is very high, if the theoretical background is not good enough. This aspect has generated a great deal of concern (Borruso, 2013, p. 11; Bord, 2013, p. 54). At the Faculty of Geography within the University of Bucharest, the formation of these competences begins in the first semester of the $1^{\text {st }}$ year of study at several disciplines (Land Surveying, Methods and Techniques of Cartographic Representation, Hydrology, etc.) and continues during the coming years with other disciplines.

The teaching experience also proved that it is more efficient to develop a particular competence when this is associated with several themes connected with the same subject (in this case the topography and its mapping), which are dealt with at different study disciplines. As a result, in order to develop the competence of developing hypsometric maps, we decided to associate the following topics: (1) the graphic interpolation and manual drawing of contour lines and (2) the creation of a hypsometric map by using the computer (with discrete colour bands), starting from the same spot elevation map.

The objectives of the present study are the following: (a) analysing the procedure to manually interpolate and draw contour lines; (b) analysing the procedure to accomplish a digital hypsometric map based on spot elevations by using a computer-assisted cartography software (which uses automatic and semi-automatic interpolation); (c) analysing the usefulness of combining the two topics in competence formation.

In order to achieve the proposed targets, we organized the activity meant to form the competence of graphic interpolation and manual drawing of contour lines, followed by the activity of developing the competence of creating a digital terrain map by using hypsometric tinting, starting from the spot elevations. The purpose of associating the two topics (using the same data) was to make the students interpolate the contour lines manually, in order to understand what hides "behind" the button that generates an automatic interpolation. 
Hypsometric maps derive from the maps with contour lines, which, in their turn, are an application of the isoline method. However, between the two, there is a fundamental difference: the hypsometric map has unequal elevation steps (Grigore, 1979; Donnay, 2013), while on the contour map the isolines emphasize equal altitudinal steps (contour interval). The specialty literature expresses this difference more or less clearly. The hypsometric map is not just a contour map on which the intervals between the contour lines were coloured. The inequality of altitudinal steps brings more information, namely it makes a correlation between morphography (the qualitative aspect) and morphometry (the quantitative aspect).

More than that, the hypsometric map also relies on other geomorphological maps (showing planation surfaces, terraces, slope gradients, vertical relief-dissection, etc.), which help the geographer to establish properly the hypsometric steps, so that to show correctly and suggestively the hypsometric features of the geomorphological landscape (Grigore, 1979, pp. 150-154). The use of GIS software produces more and more inaccurate hypsometric maps, because the user is free to choose any altitudinal steps, and the first option, which is a wrong one, is to choose equal altitudinal steps.

Although most of the hypsometric maps found in the graduation papers, Ph.D. papers and other scientific studies are accomplished by using the sequence contour lines (vector) - digital elevation model (raster) establishing the hypsometric steps (also raster), our intention was to begin the task from spot elevations, by observing the following sequence: spot elevations (vector) - contour lines (vector, through interpolation) establishing the hypsometric steps (vector). The reason of this approach was that we wanted the students to understand the interpolation principle (by experimenting it manually), because this is used for developing maps with isolines (isotherms, isohyets, etc.).

Nevertheless, unlike the hypsometric maps, on these maps the value intervals between the isolines are equal. When using the isoline method, the intervals between the lines of equal value can be coloured or shaded with hachures (Albotă et al., 2009, p. 227), thus obtaining isopleth maps, on which the isolines can be preserved or not (Le Fur, 2007, p. 102). However, the hypsometric colour bands method is a specific one; on small-scale cartographic representations, it consists in the ordered colouring of the contour intervals: different blue shades for water bodies; green for plains; yellow for tablelands; and brown for mountains. It is possible to use as many as 10-12 colours (Albotă et al., 2009, pp. 229-230). These altitudinal steps show once again that the vertical intervals between the contour lines are unequal. 


\section{MATERIALS AND METHOD}

Subject sample. The 111 subjects of the teaching experiment were $1^{\text {st }}$ year students in Cartography (Faculty of Geography, University of Bucharest) from the 2014-2015 and 2015-2016 academic years, who accomplished the respective tasks. Although all the students had studied with the same professor and had received the same learning materials, we noticed differences in their initial formation, which influence the results of the present study and prevent us from drawing general conclusions. These differences were mirrored both by the pace in which the students learned the theoretical aspects and by the competence level they acquired.

\section{Method}

Practically, this teaching experiment has successively integrated two themes at different disciplines (Table 1), with the purpose of developing various competences related to terrain representation, based on a profound understanding and correlation of the concepts and procedural steps. In order to present the experiment as briefly as possible, it is important to make two points: (a) both integration activities were accomplished based on the same spot elevation map (so that the students could compare the manual interpolation with the one obtained with the computer, as well as the resulting representations; Fig. 1); (b) the students did not develop hypsometric maps through the colour bands method before finishing the interpolation and the manual drawing of contour lines. The common concepts of the two tasks are given in Table 1.

Table 1. The tasks and the disciplines employed for the teaching experiment of integrated competence development

\begin{tabular}{|l|l|l|}
\hline \multicolumn{1}{|c|}{ Task } & \multicolumn{1}{c|}{ Discipline } & \multicolumn{1}{c|}{ Common concepts } \\
\hline $\begin{array}{l}\text { Interpolation and contour } \\
\text { lines drawing }\end{array}$ & Land Surveying & $\begin{array}{l}\text { Spot elevation, contour } \\
\text { line, contour line } \\
\text { interpolation, isoline } \\
\text { method, topography, } \\
\text { cartographic } \\
\text { representation }\end{array}$ \\
\hline $\begin{array}{l}\text { Developing the } \\
\text { hypsometric map starting } \\
\text { from spot elevations }\end{array}$ & $\begin{array}{l}\text { Methods and Techniques of } \\
\text { Cartographic } \\
\text { Representation }\end{array}$ & \multicolumn{2}{|c|}{} \\
\hline
\end{tabular}

The students had already been given the basic notions during the Land Surveying course: the methods of representing the terrain on maps (contour lines method, elevation method, hypsometric tints method, etc.). From the Methods and Techniques of Cartographic Representation, the students knew the following things: the isoline method, the types of layers used in digital cartography (point, line, area), as well as the Phildigit and 
Developing the Competence of Representing the Topography by Discrete Colour ...

Philcarto (http://philcarto.free.fr/) software, which are currently used at the Faculty of Geography (Osaci-Costache, 2012).

(A.1.) Developing the competence to graphically interpolate and manually draw contour lines stating from spot elevations was accomplished based on a general model (Dulamă, 2009, p. 247; 2010, p. 323; Dulamă et al., 2016), yet adapted to the specific task (Table 2). Similarly happened in the case of the second competence, namely developing a hypsometric map by using the colour bands method (Table 3 ), according to the methods described in the literature (Dulamă, 2010, pp. 52-53).

Table 2. The components that help developing the competence to graphically interpolate and manually draw contour lines

\begin{tabular}{|l|l|}
\hline $\begin{array}{l}\text { Declarative } \\
\text { knowledge }\end{array}$ & $\begin{array}{l}\text { Concepts: elevation, spot elevation map, control points, topography } \\
\text { details, analytical interpolation (by calculation), graphical } \\
\text { interpolation, contour line (index, intermediate, supplementary), } \\
\text { contour interval, interpolation graph. } \\
\text { The basic concept of contour lines interpolation: it is assumed that } \\
\text { between two adjacent spot elevation points the slope gradient is } \\
\text { uniform. } \\
\text { Rules for the graphical interpolation of contour lines } \\
\text { R 1. The interpolation graph should contain round values, which will } \\
\text { be the values of the resulting contours. } \\
\text { R 2. The adjacent elevations will be interpolated in pairs of two, } \\
\text { taking only the points situated along the line of the highest gradient } \\
\text { (Couet \& Dubuisson, 1982, p. 36). } \\
\text { R 3. It is forbidden to jump over points. } \\
\text { Rules for drawing contour lines } \\
\text { R 1. A line will join the points having the same round value. } \\
\text { R 2. To make the task easier, one should start from the highest } \\
\text { value (usually around a peak), taking into account that the } \\
\text { contours are closed curved lines. } \\
\mathrm{R} \text { 3. One should pay attention to the stream network and the } \\
\text { interfluves. } \\
\mathrm{R} \text { 4. In the end, the contour lines will need to be smoothed, but } \\
\text { without turning them into arbitrary curved lines. }\end{array}$ \\
$\begin{array}{l}\text { Observing the rules and the stages of work. } \\
\text { Each student within the team will do the interpolation and drawing } \\
\text { of contour lines. } \\
\text { The interpolation and drawing of contour lines will be accomplished } \\
\text { during a given period. }\end{array}$ \\
knowledge
\end{tabular}




\begin{tabular}{|c|c|}
\hline $\begin{array}{l}\text { Procedural } \\
\text { knowledge }\end{array}$ & $\begin{array}{l}\text { Making an interpolation graph. } \\
\text { Establishing the contour intervals depending on the spot elevation } \\
\text { values. } \\
\text { Interpolating the values and establishing the contour points (with } \\
\text { round values). } \\
\text { Drawing the contour lines on the spot elevation map by connecting } \\
\text { the contour points having the same round values. } \\
\text { Doing, where necessary, supplementary interpolations on } \\
\text { secondary directions (taking into account the interfluves and the } \\
\text { stream system). } \\
\text { Smoothing the contour lines. }\end{array}$ \\
\hline $\begin{array}{l}\text { Procedural } \\
\text { approach }\end{array}$ & $\begin{array}{l}\text { Stage } 1 \text {. Make the interpolation graph. } \\
\text { Step 1. Analyse the spot elevations and establish the round values } \\
\text { and the adequate contour interval (depending on the relief } \\
\text { amplitude and the map scale). } \\
\text { Step 2. Taking into account the round values draw on a tracing } \\
\text { sheet a number of straight lines, } 3-5 \mathrm{~cm} \text { long, at } 2-3 \mathrm{~mm} \text { from each } \\
\text { other; write on one side, next to the lines, the values established at } \\
\text { Step 1, starting with the highest value at the top. } \\
\text { Stage 2. Graphical interpolation of contour lines } \\
\text { Step 1. On the spot elevation map, unite with a ruler and a pencil } \\
\text { the neighbouring points, two by two (taking only the points situated } \\
\text { along the highest slope gradient) - Fig. 1b. } \\
\text { Step 2. Put the tracing sheet between two neighbouring points on } \\
\text { the slope elevation map and rotate it so that the two elevations } \\
\text { may fall on their correct altitudinal position (between the lines } \\
\text { drawn on the tracing sheet). } \\
\text { Step 3. Prick the points in which the lines connecting the spot } \\
\text { elevations intersect the lines drawn on the tracing paper and write } \\
\text { the altitudinal value indicated on the interpolation graph. } \\
\text { Stage 3. Drawing the contour lines } \\
\text { Step 1. Starting from the highest value, draw contour lines so that } \\
\text { to connect the contour points with the same value. Pay attention to } \\
\text { the peaks, the interfluves, and the stream network (Fig. 1c). } \\
\text { Step 2. Smooth the contour lines (taking into account the stream } \\
\text { system and the interfluves). } \\
\text { Step 3. Draw the final contour lines with brown pencil (Fig. 1d). }\end{array}$ \\
\hline
\end{tabular}


Developing the Competence of Representing the Topography by Discrete Colour ...

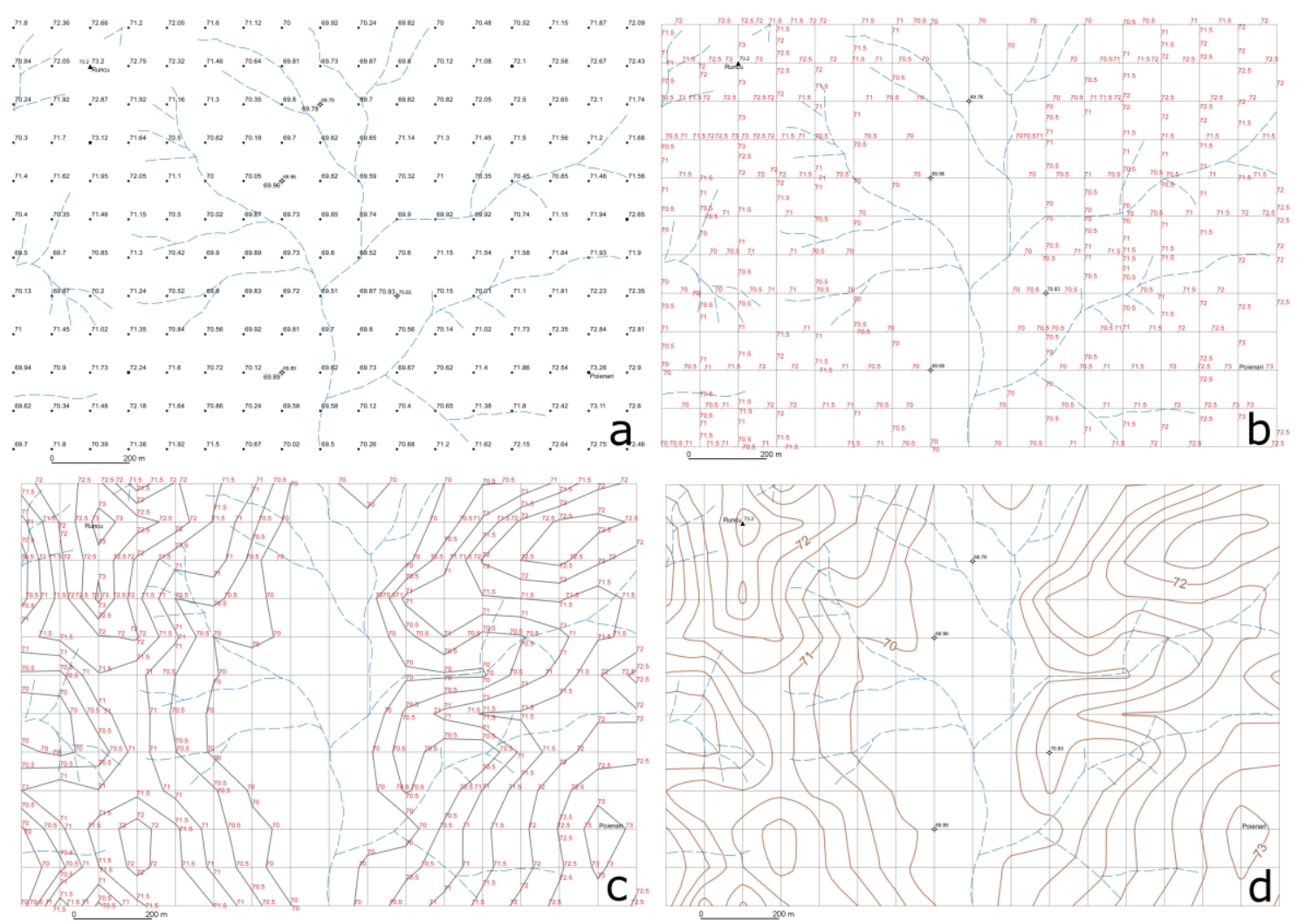

Fig. 1. a - The spot elevation map underlying the tasks performed at both disciplines (source: Gagea \& Iacobescu, 1993, with minor alterations); b Square method; c - Contour lines; $d$ - The final contour lines

Table 3. The components that help developing the competence of creating a hypsometric map by using discrete colour bands

\begin{tabular}{|l|l|}
\hline $\begin{array}{l}\text { Declarative } \\
\text { knowledge }\end{array}$ & $\begin{array}{l}\text { Concepts: cartographic methods, topography, contour line, slope } \\
\text { elevation, isoline method, hypsometric colour bands, quantitative } \\
\text { variation, discrete representation, sequential colours. } \\
\text { Rules for developing a hypsometric map by using discrete colour } \\
\text { bands } \\
\mathrm{R} \text { 1. The map title describes the theme or subject of the map } \\
\text { (hypsometry), not the method used for creating the map. } \\
\mathrm{R} 2 \text {. The hypsometric steps are established by taking into account } \\
\text { the detailed classifications given in the theoretical part of the } \\
\text { lesson: (a) the classification by selecting the limits of the altitudinal } \\
\text { steps corresponds to the elevations that bound the equal-area } \\
\text { surfaces; (b) the classification of altitudes in geometric } \\
\text { progression; (c) the classification by summing up two previous } \\
\text { altitudinal intervals (Donnay, 2013). } \\
\mathrm{R} 3 . \text { The altimetric steps (shown by colour bands) are separated by } \\
\text { contour lines with uneven contour intervals (Donnay, 2013). }\end{array}$
\end{tabular}


$\mathrm{R}$ 4. The limits of the altimetric classes are contiguous and have round values.

$\mathrm{R}$ 5. The number of classes depends on the relief altitude, the classification method employed and the map scale, but generally, it must be high, between 7 and 10 classes (Donnay, 2013).

R 6. As far as the colours are concerned, one must apply the rules of quantitative variation: sequential series (which refers to the continuous increasing or decreasing between a maximum and a minimum, without a significant central value; for instance, the elevations above sea level) or divergent series (when there is a significant central value, which divides the value series into two categories: the elevations above and below the sea level) (Donnay, 2013).

$\mathrm{R}$ 7. The colours of the hypsometric steps should belong to the colour range used for relief representation: according to Donnay (2013), on small-scale maps with high amplitudes, one can use a divergent spectral palette.

$\mathrm{R}$ 8. Although the existent software has several colour scales, these will be avoided if they have nothing to do with topography and with its elevations and the amplitude (see R 7.).

R 9. For bathymetry, blue tints should be used (Brewer, 2012).

$\mathrm{R} 10$. For the maps with several thematic planimetric elements, one may desaturate the tints by $50 \%$ or even more to make them softer (Donnay, 2013).

$\mathrm{R}$ 11. When using a software that is not able to order the legend automatically, the following rule should apply: the highest hypsometric steps will be shown at the top, so that to correspond with the vertical increase of the altitudes; if there are both negative and positive values, then the negative ones will be at the bottom and the positive ones at the top.

$\mathrm{R}$ 12. The legend must also show the measurement units. There are countries (Italy, for instance) where the rule is to specify that positive altitudes are measured "above sea level".

R 13. The map should contain basic topography features.

$\mathrm{R}$ 14. The symbols for elevations (small circles and triangles) have an adequate form and size; there is a difference between peak and elevation; these symbols and values will be shown in black, as is happens on the topographic map.

$\mathrm{R} 15$. The other symbols (for the stream network) will be lines differentiated according to the type of flow (temporary or permanent), having an adequate colour.

$\mathrm{R} 16$. The map should have a scale.

$\mathrm{R}$ 17. The map should contain toponyms and other necessary inscriptions (elevation values). Depending on situation, diacritical marks, a Sans-serif font and an adequate size will be used. The colours of the inscriptions should correspond to the element they 
Developing the Competence of Representing the Topography by Discrete Colour ...

\begin{tabular}{|c|c|}
\hline & $\begin{array}{l}\text { refer to. One should observe the rules of cartographic writing and } \\
\text { positioning. } \\
\mathrm{R} 18 \text {. The arrow indicating the North should be put on the map only } \\
\text { if necessary (when the north is not given by the top margin of the } \\
\text { page). } \\
\mathrm{R} 19 \text {. One should mention the source of the data used for } \\
\text { interpolation, the method of interpolation, and the errors. } \\
\mathrm{R} 20 \text {. If the map is realised with Philcarto, one should mention } \\
\text { "Developed with Philcarto, http://philcarto.free.fr/". } \\
\mathrm{R} 21 \text {. One should observe the rules of fitting into the page and the } \\
\text { aesthetic requirements. }\end{array}$ \\
\hline $\begin{array}{l}\text { Attitudinal } \\
\text { knowledge }\end{array}$ & $\begin{array}{l}\text { Observing the rules and the work stages. } \\
\text { The map will be realised with personal effort. } \\
\text { The map will be realised during a given period. }\end{array}$ \\
\hline $\begin{array}{l}\text { Procedural } \\
\text { knowledge }\end{array}$ & $\begin{array}{l}\text { Good knowledge of Phildigit and Philcarto software. } \\
\text { Good knowledge of a software with calculus functions (Microsoft } \\
\text { Excel, OpenOffice Calc, LibreOffice Calc, etc.). } \\
\text { Digitizing the spot elevation map in Phildigit: creating point, line, } \\
\text { and area layers. } \\
\text { Introducing the attributes (elevations) in a spreadsheet. } \\
\text { Good understanding of the various interpolation methods } \\
\text { (Triangulation, Kriging, etc.). } \\
\text { Associating the digitized database with the attribute table (in } \\
\text { Philcarto) and selecting the map type, the interpolation method and } \\
\text { the contour interval. } \\
\text { Representing other elements (river network, map scale, etc.). } \\
\text { Finishing the legend. } \\
\text { Finishing the map. }\end{array}$ \\
\hline $\begin{array}{l}\text { Procedural } \\
\text { approach }\end{array}$ & $\begin{array}{l}\text { Stage 1. Digitizing the slope elevation map. } \\
\text { Step 1. Upload the spot elevation map (.bmp, .jpg, .gif, .tif) in } \\
\text { Phildigit. } \\
\text { Step 2. Create the necessary vector layers: point (for elevations), } \\
\text { line (for the river network), and area (for various area features). } \\
\text { Step 3. Introduce the attributes (altitudes) in a spreadsheet, taking } \\
\text { into account the features of Phildigit and Philcarto software. } \\
\text { Stage 2. Developing the hypsometric map by using the colour } \\
\text { bands method. } \\
\text { Step 1. Associate the digitized database with the attribute table in } \\
\text { Philcarto, paying attention that the elevation values be understood } \\
\text { as "relation". } \\
\text { Step 2. Select the elements that will be represented (streams, etc.) }\end{array}$ \\
\hline
\end{tabular}




\begin{tabular}{|l|l|}
\hline and the necessary symbols and colours. \\
Step 3. Select the map type (isoline map; by using this command). \\
Step 4. Make the necessary adjustments (interpolation type, \\
minimum and maximum limits, the limits of the classes, resolution, \\
showing the spot elevations, colours) - Fig. 2a. \\
Step 5. Finish the map by using Inkscape (https://inkscape.org/) or \\
Gimp (https://www.gimp.org/) software tools (Fig. 2b).
\end{tabular}

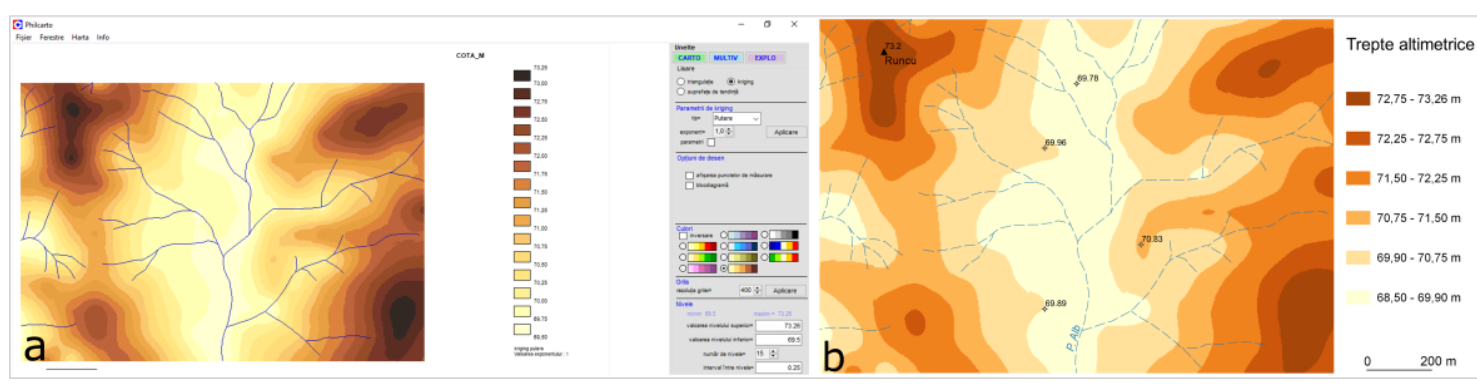

Fig. 2. a - The isopleths map in Philcarto software (http://philcarto.free.fr/); b - The method of discrete hypsometric colour bands

(A.2.) During the first semester of the $1^{\text {st }}$ year of study, at the practical activities pertaining to the Land Survey course, the subjects (organized in groups of 20-25 students) were involved in an integrated activity meant to develop the competence to graphically interpolate and manually draw contour lines, with the purpose of experimenting the procedure. After the theme was completed, the students were asked, during the practical activities pertaining to Methods and Techniques of Cartographic Representation course, to develop a hypsometric map by using the colour bands method, because they already knew the interpolation principle that was behind the computer's work. Similarly to other studies (Osaci-Costache et al., 2013), both activities were designed and organized according to some models presented in the specialty literature (Dulamă, 2010, pp. 7582; 2011, pp. 98-108). These activities had several stages.

(A.2.1) The presentation of theoretical aspects was divided between the two disciplines. At Land Surveying, the interpolation principle and its practical application were emphasized. Part of the time was reserved for explanations, and the rest for tasks.

The theoretical aspects of the graphical interpolation and the drawing of contour lines are tackled in many works (Couet \& Dubuisson, 1982, pp. 35-41; Năstase, 1983, pp. 166-167; Boș \& Iacobescu, 2007, pp. 429-431; Osaci-Costache, 2008, pp. 46-48; Cocoș \& Cocoș, 2013; pp. 239-242; Cannarozzo et al., 2017, etc.), which were used for documentation. However, there are also works that discuss the method of developing hypsometric maps (Iacobescu \& Cojocaru, 1966, pp. 107-109; Grigore, 1979, pp. 150-154; Donnay, 2013, etc.). 
We insisted both on the similarities and on the differences between the two methods used for representing the topography (contour lines and hypsometric tints). Thus, although the spot elevations, the contour lines and the interpolation are common issues for the two themes, the main difference between representing the terrain by contour lines method and representing it by hypsometric tints is the vertical distance between two adjacent isohypses. In the first case, there is a constant distance (contour interval). In the second case, the discrete representation of the hypsometric colour bands refers to the delimitation of a number of contiguous intervals, coloured and delimited by contour lines with different vertical intervals (Donnay, 2013). The advantages of discrete representation (Fig. 2a, 2b) are the following: an easy reading and understanding of the altitudinal steps and the possibility to adapt the representation to the planimetric elements of the map (Donnay, 2013).

As far as the hypsometric map is concerned, a widespread mistake is the setting of arbitrary limits (usually at even intervals) for the hypsometric steps, for instance every $100 \mathrm{~m}$, without taking into account the rules and the classifications presented in the specialty literature. According to Donnay (2013), the discrete representation of the hypsometric tints has three possible solutions: (a) classification based on hypsographic curves - the limits of the altitudinal steps correspond to the altitudes that delimit equalarea intervals and not equal-altitude intervals; (b) classification in geometric progression (especially for the territories with significant relief depths); (c) classification by summing up the two previous altitudinal intervals. The geomorphological works also insist of the inequality of the altimetric steps, as we have shown in the Introduction.

Because the students were lacking geomorphological knowledge and the employed software created only isopleth maps, the hypsometric steps were established by the professor. The purpose was to experiment the use of the isoline method, which underlies the hypsometric colour bands method. It does not replace the geomorphology theme (which will be tackled in the $2^{\text {nd }}$ year of study), but only prepares it.

Another focus was the legend, because many maps have errors in this respect. Thus, the correct positioning of the steps can be done in two ways: (a) vertical, of ascending type, with the highest altitude on top; (b) horizontal. Many software tools cannot arrange these steps automatically. Philcarto is an exception (Fig. 2a), which is why the students were warned that not all the software could do that.

(A.2.2.) The explanation of the working procedures and of the steps that need to be taken was done during the practical activities. A week in advance, the students were given a digital spot elevation map, which was to be used later for the development of both competences. For the interpolation and manual drawing of the contour lines, each team, consisting of two students, had to print the map on an A4 sheet of paper, while for the hypsometric map each student used a digital map made in Phildigit free software. Computer-assisted cartography programs were used 
and not a GIS program, because the students did not attend a GIS course until then, but they knew how to use the Phildigit and Philcarto software.

(A.2.3.) The presentation and the accomplishment of the work tasks were different, depending on the competence aimed at being developed. At Land Surveying, the practical activity was carried out during a two-hour session (Table 3), and the same happened at Methods and Techniques of Cartographic Representation (Table 4).

Table 3. The work tasks during the practical activities at Land Surveying, aimed at developing the competence to graphically interpolate and manually draw contour lines

\begin{tabular}{|l|l|l|l|}
\hline Work task & Necessary materials & Procedure & Work time \\
\hline $\begin{array}{l}\text { Graphical interpolation } \\
\text { of the contour lines, } \\
\text { directly on the spot } \\
\text { elevation map }\end{array}$ & $\begin{array}{l}\text { Spot elevation map, } \\
\text { pins, ruler, tracing } \\
\text { paper, pencils }\end{array}$ & $\begin{array}{l}\text { Manually, in } \\
\text { teams of two } \\
\text { students }\end{array}$ & 60 minutes \\
\hline $\begin{array}{l}\text { Drawing the contour } \\
\text { lines directly on the } \\
\text { spot elevation map }\end{array}$ & $\begin{array}{l}\text { Coloured pencil } \\
\text { (brown) }\end{array}$ & $\begin{array}{l}\text { Manually, in } \\
\text { teams of two } \\
\text { students }\end{array}$ & 30 minutes \\
\hline $\begin{array}{l}\text { Comparing the results } \\
\text { obtained by each team }\end{array}$ & $\begin{array}{l}\text { The maps obtained } \\
\text { by each team }\end{array}$ & $\begin{array}{l}\text { Comparison, all } \\
\text { the students in } \\
\text { the group }\end{array}$ & 10 minutes \\
\hline
\end{tabular}

Table 4. The work tasks at Methods and Techniques of Cartographic Representation, aimed at developing the competence to create a digital hypsometric map by using the colour bands method

\begin{tabular}{|l|l|l|l|}
\hline Work task & Software & Procedure & Work time \\
\hline $\begin{array}{l}\text { Digitizing the spot } \\
\text { elevations }\end{array}$ & Phildigit & $\begin{array}{l}\text { Computerized, } \\
\text { individually }\end{array}$ & 25 minutes \\
\hline $\begin{array}{l}\text { Introducing the attributes } \\
\text { (altitudes, spot } \\
\text { elevations) }\end{array}$ & $\begin{array}{l}\text { LibreOffice Calc, } \\
\text { Microsoft Excel, etc. }\end{array}$ & $\begin{array}{l}\text { Computerized, } \\
\text { individually }\end{array}$ & 10 minutes \\
\hline $\begin{array}{l}\text { Creating the hypsometric } \\
\text { map by using the colour } \\
\text { bands method }\end{array}$ & Philcarto & $\begin{array}{l}\text { Computerized, } \\
\text { individually }\end{array}$ & 10 minutes \\
\hline $\begin{array}{l}\text { Comparing the individual } \\
\text { results }\end{array}$ & $\begin{array}{l}\text { The maps obtained } \\
\text { individually }\end{array}$ & $\begin{array}{l}\text { Comparison, all } \\
\text { the students in } \\
\text { the group }\end{array}$ & 10 minutes \\
\hline $\begin{array}{l}\text { Comparing the } \\
\text { interpolation methods } \\
\text { (manual and } \\
\text { computerized) }\end{array}$ & $\begin{array}{l}\text { The maps obtained } \\
\text { at both disciplines }\end{array}$ & $\begin{array}{l}\text { Comparison, all } \\
\text { the students in } \\
\text { the group }\end{array}$ & 5 minutes \\
\hline
\end{tabular}


Developing the Competence of Representing the Topography by Discrete Colour ...

(A.2.4.) Checking competence development was done differently. At Land Surveying, were analysed the contour maps accomplished during the practical activities, both during their creation and, at the end of the activity, but without giving a score. At Methods and Techniques of Cartographic Representation, the students were asked to present the map two weeks after the end of the activity, in order to be evaluated and to be given a score (maximum 1 point, which was to be added at the final mark). The evaluation tool had been used before (Osaci-Costache et al., 2013) and consisted in an analytical evaluation grid with dichotomous scale (Dulamă, 2010 , p. 86 , p. 105 ; 2011 , pp. $106-107$, pp. $120-122$ ). Our intention is to discuss the evaluation in a different paper.

\section{RESULTS AND DISCUSSION}

1) The knowledge integrated in the competence to graphically interpolate and manually draw contour lines based on a spot elevation map have been included in Table 2 (15 concepts of declarative knowledge, 7 rules that must be observed, 3 items of attitudinal knowledge and 6 items of procedural knowledge). The knowledge integrated in the competence of creating digital maps with hypsometric tints, by using a computer-assisted cartography program, include the following: 10 concepts of declarative knowledge, 21 rules that must be observed, 3 items of attitudinal knowledge and 8 items of procedural knowledge (Table 3).

As with other studies, we could see once more that the division of the knowledge integrated in the competences (like in Table 2 and Table 3) was very useful, especially because we could divide and organize the concepts, stages, rules, etc., while the presentation was easy to be followed and implemented, which was beneficial for the teaching activity. However, the two topics approached help not only the development of the two discussed competences (to interpolate and draw contour lines; to create a hypsometric map by using the colour bands method), but also to develop other competences as well (to analyse relief amplitude, to make a interpolation graph, to establish round values, to create a database, etc.).

At the same time, they help the improvement of the already acquired competences (the competence to make a legend, to digitize, etc.). Yet, for brevity and for a more synthetic and logical presentation (as we could not separate the interpolation from the drawing of contour lines), we resorted to the integrated description of the competences, reducing them only to two. Besides, in order to develop the competence to interpolate and draw the contour lines the students worked in pairs, because teamwork is a competence required by the employers.

2) The procedural approaches for both competences were also included in Table 2 and Table 3, being detailed on stages and steps (Dulamă, 2009, p. 
247 , p. $410 ; 2010$, p. 323). Both procedural approaches were presented to the students during the practical activities, before receiving the work task. The advantage of working in class was that the students were permanently monitored and were given immediate feedback.

In order to develop the competence to interpolate and draw contour lines, all the stages were explained so that to be applied manually, with the precise purpose that the students understand the principle. To make them also understand what algorithms GIS software or computer-assisted programs could apply, the analytical method of interpolation was explained to them, as being one of the available methods. Starting from the same spot elevation map, the pairs of students observed the working procedure and at the end of the practical activities, being asked to compare the results, they saw that the contour maps were almost identical.

As far as the second competence is concerned (creating a hypsometric map by using the colour bands method), all procedural stages were adapted to the computer use, as this is the present method of developing graphic and cartographic materials. For this reason, the students were not asked to draw in ink on tracing paper the contour lines obtained at Land Surveying through the graphical method. The purpose was only to understand the interpolation, which helps the development and the improvement of several methods that support the use of maps, the reading of terrain features, etc. Although all the students started from the same data, at the end of the practical activities, when they compared their hypsometric maps, they found them almost identical (in terms of hypsometric steps, colours, density of the river system, etc.), but different at the same time in comparison with the contour maps obtained at Land Surveying.

In both situations, the students developed what Brien (1997) called reproductive competence. This is achieved when the student has the necessary declarative knowledge and applies a method learned from the professor by making use of a known algorithm (Dulamă, 2011, p. 43). Although it would have been desirable to form a productive competence (Brien, 1997), this thing was not possible, because the students should have possessed more geomorphology knowledge (but this discipline is taught during the $2^{\text {nd }}$ year of study). From the reproductive competence, the students will be able to develop later a productive competence, which will allow them not to apply rigidly the procedural approach any more, but to make the necessary adjustments in order to emphasize the essential topography features (Dulamă, 2010, p. 52).

3) The usefulness of corroborating the two topics for competence development. The integrated and successive presentation of the two topics (at different disciplines), which have both common and particular concepts allowed the students to deepen their understanding and to correlate the declarative, attitudinal and procedural knowledge, so that to apply the necessary procedures and rules in a constructive manner, based on their deep understanding. Consequently, the transfer of knowledge should foster creativity and productive competence. Putting the students to compare the 
Developing the Competence of Representing the Topography by Discrete Colour ...

results obtained manually by each team, on the one hand and the results obtained manually with the computer-assisted outcomes, on the other hand, helped them to understand more thoroughly the concepts, to acquire a critical attitude and to become "reflexive students" (Cinque, 2013).

\section{CONCLUSIONS}

The main outcome of this teaching experiment is that the students were helped to correlate the notions, the concepts, etc. so that to base their procedural approaches on the understanding of the causes, theories, formulas, etc. We left aside the separate presentation of the notions, because this integration of concepts and competences is beneficial for the professional development of the students and for increasing the quality of teaching in geographical higher education.

\section{References}

Albotă, G.A., Atudorei, M., Năstase, A., Neamțu, M., Ulea, E. \& Zegheru, N. (2009). Dicționar enciclopedic de geodezie, topografie, fotogrammetrie, teledetecție, cartografie, cadastru. București: Nemira.

Bord, J.P. (2013). Cartes et Géomatique. Cartes \& Géomatique, 218: 51-54.

Borruso, G. (2010). La "nuova cartografia" creata dagli utenti. Problemi, prospettive, scenari. Bollettino dell'Associazione Italiana di Cartografia, 138: 241-252.

Boș, N. \& Iacobescu, O. (2007), Topografie modernă. București: Editura C.H. Beck.

Brewer, C.A. (2012). ColorBrewer 2.0. Color Advice for Cartography. Retrieved 16 December 2017, from http://colorbrewer2.org

Brien, R. (1997). Science cognitive \& formation. Montreal: Presses de I'Université de Québec.

Cannarozzo, R., Cucchiarini, L. \& Meschieri, W. (2017). Misure, rilievo, progetto, per costruzioni, ambiente e territorio, quinta edizione. Bologna: Zanichelli.

Cinque, M. (2013). "Lo studente riflessivo": I'uso di dispositivi mobili tra formazione on-the job e PLN (Personal Learning Network). Form@re - Open Journal per la formazione in rete, 11(73), 38-50, DOI: http://dx.doi.org/10.13128/formare-12554

Cocoș, O. \& Cocoș, A. (2013). Cartografie - Topografie. București: Editura Transversal.

Couet, R \& Dubuisson, B. (1982). Cours de dessin topographique. Paris: Eyrolles. 


\section{GABRIELA OSACI-COSTACHE, OCTAVIAN COCOŞ}

Donnay, J.-P. (2013). Guide de rédaction des cartes thématiques. Méthodes et consignes. Liège: Unité de Géomatique, Université de Liège.

Dulamă, M.E. (2009). Cum îi învăţăm pe alţii să înveţe. Teorii şi practici didactice. Cluj-Napoca: Editura Clusium.

Dulamă, M.E. (2010). Didactică axată pe competenţe. Cluj-Napoca: Presa Universitară Clujeană.

Dulamă, M.E. (2010). Fundamente despre competenţe. Teorie şi aplicaţii. ClujNapoca: Presa Universitară Clujeană.

Dulamă, M.E. (2011). Despre competenţe. Cluj-Napoca: Presa Universitară Clujeană.

Dulamă, M.E., Ilovan, O.-R. \& Niţoaia, A. (2016). Forming and Assessing the Competence to Elaborate Proposals of Spatial Planning Measures for Hydrographical Basins. PedActa, 6(1), 16-27.

Gagea, L. \& Iacobescu, V. (1993). Cartografie (Desen cartografic). București: Editura Didactică și Pedagogică.

Grigore, M. (1979). Reprezentarea grafică și cartografică a formelor de relief. București: Editura Academiei R.S.R.

Iacobescu, V. \& Cojocaru, D. (1966). Cartografierea și reproducerea hărților. București: Editura Didactică și Pedagogică.

Le Fur, A. (2007). Pratiques de la cartographie, $2^{\mathrm{e}}$ édition. Paris: Armand Colin.

Năstase, A. (1983). Cartografie-Topografie. București: Editura Didactică și Pedagogică.

Osaci-Costache, G. (2008). Topografie-Cartografie. Metodologie, exemple rezolvate şi 355 de aplicaţii. Bucureşti: Editura Universitară.

Osaci-Costache, G. (2012). La formazione delle competenze professionali nella specializzazione in Cartografia attraverso I'uso delle fonti cartografiche Web e dei programmi gratuiti, liberi e Open Source. Bollettino dell'Associazione Italiana di Cartografia, 144-145-146, 123-135.

Osaci-Costache, G., Dulamă, M.E. \& Ilovan, O.-R. (2013). Forming and Assessing the Competence to Elaborate Topographic Profiles. Studia Universitas BabeşBolyai, Geographia, 58(2), 199-220. 